\title{
A Functional Perspective for Reef Benthic Communities: Temporal Trends in the Only Atoll in Southern Atlantic
}

Vitor André Passos Picolotto ( $\sim$ picolottovitor@gmail.com )

Universidade Federal de Santa Catarina https://orcid.org/0000-0003-2545-6090

Anaide W. Aued

Universidade Federal de Santa Catarina

Luis C. P. Macedo-Soares

Universidade Federal de Santa Catarina

Julia Biscaia Zamoner

Universidade Federal de Santa Catarina

Bárbara Segal

Universidade Federal de Santa Catarina

\section{Research Article}

Keywords: Rocas Atoll, functional diversity, functional richness, functional entropy, ecosystem functions, tridimensional complexity.

Posted Date: July 9th, 2021

DOI: https://doi.org/10.21203/rs.3.rs-683029/v1

License: (9) This work is licensed under a Creative Commons Attribution 4.0 International License.

Read Full License 


\section{Abstract}

Reef benthic communities provide many important ecosystem functions such as nutrient cycling, carbonate accretion and tridimensional complexity. Yet, reefs worldwide face an uncertain future, being threatened by local and global impacts. As an alternative approach to evaluate communities' changes, functional ecology aims to understand how species shape the environment and how functions conduct ecosystems' dynamics. The aim of this study was to investigate the temporal dynamics (2013-2019) of the reef benthic community in the most pristine reef in Brazil, Rocas Atoll, using a functional diversity approach. We identified 48 organisms grouped into 17 functional entities (according to their traits' combination), considering all sampling years. Benthic community was temporally dominated by functional entities responsible for providing low reef tridimensional complexity (represented mainly by turf algae). This dominance reflected in low values of functional entropy, due to uneven abundances distribution between unique functional entities, those that have unique trait combination. Functional richness oscillated over years, but did not show great changes in functional spaces, maintaining an equity in the number of functional entities and indicating stability of reef functions in Rocas Atoll, even with unequal abundances' distribution. Our study is the first to use a functional approach in temporal scale and represents a baseline for South Atlantic, since it provides the actual state of reef benthic communities using a functional approach, in an environment with no direct anthropic impacts. This can help to predict the effects on some ecosystem functions caused by local and global changes and its consequence for ecosystem services.

\section{Introduction}

Despite covering small areas in the oceans (Spalding and Grenfell 1997), reefs are the richest marine ecosystems, being comparable to tropical forests (Connel 1978; Costanza et al. 1997). In reefs, benthic communities deliver many important ecosystem functions (Solan et al. 2004; Brandl et al. 2019), such as nutrient cycling (Costanza et al. 1997), carbonate accretion and tridimensional complexity (Zawada et al. 2019a). Tridimensional complexity is a reef function that directly affects the habitat formation for many species, dictating how organisms interact with the environment and with each other (Zawada et al. 2019a). Yet, reefs worldwide face an uncertain future towards changes in the Anthropocene (Williams and Graham 2019), being threatened by local (e.g. overfishing and pollution) and global (e.g. climate change) impacts (Bellwood et al. 2004; Halpern et al. 2008; Munday et al. 2008; Hughes et al. 2010). Those impacts can compromise reef resilience, leading to phase shifts (Smith et al. 2016) and reef flattening (Alvarez-Filip et al. 2009), threatening the sustainability and stability of ecosystem functions and services (Nyström et al. 2000; Cardinale et al. 2012).

As an alternative approach to evaluate communities' changes (Mouillot et al. 2013), functional ecology aims to understand how species shape the environment and how functions conduct ecosystems' dynamics (Williams and Graham 2019). By using species traits, functional diversity has become increasingly appropriate to evaluate and to monitor communities (Ernst et al. 2006), by accessing 
al. 2013; Biggs et al. 2020). On marine environments, functional approaches have been widely applied for fishes and invertebrates (Bremner et al. 2003, 2006; Halpern and Floeter 2008; Mouillot et al. 2008, 2014; Villeger et al. 2010; Bolam et al. 2016; Gusmao et al. 2016; Bejarano et al. 2017; Richardson et al. 2017; Denis et al. 2019). Nevertheless, for reef benthic communities, studies assessing functional diversity are still scarce and mainly focused on corals (Darling et al. 2012; Madin et al. 2016; Denis et al. 2017; Zawada et al. 2019b; McWilliam et al. 2020). For the Brazilian coast, where turf algae and macroalgae are the main reef components (Aued et al. 2018), only one study has applied functional diversity indices to describe reef benthic communities (Aued et al, in prep).

Benthic communities of Brazilian reefs are dominated by turf algae and macroalgae (Aued et al. 2018). These reefs are threatened by many disturbances, as those associated to urban development, coastal runoff, marine tourism and overexploitation of reef organisms, and by ocean warming effects (Leão et al. 2019). Even in oceanic islands, which are relatively isolated from anthropogenic effects, it is possible to observe global scale impacts (Ferreira et al. 2013). For being unique and remote systems, oceanic islands reefs may operate as natural laboratories and as a reference for monitoring how these ecosystems behave through distinct spatiotemporal scales (Knowlton and Jackson 2008; Gatti et al. 2015). Moreover, spatiotemporal studies and monitoring programs support the identification of long-term changes in reef benthic communities as seen in the Caribbean, for example (Gardner et al. 2003; Côté et al. 2005; AlvarezFilip et al. 2009; Schutte et al. 2010; Contreras-Silva et al. 2020). Still, baselines for these near pristine environments are scarce (Jackson 2001; Knowlton and Jackson 2008). In this context, a long-term ecological research can help to fulfill gaps of knowledge in understanding reef communities' spatiotemporal patterns in the Brazilian oceanic islands. All four Brazilian oceanic island are Marine Protected Areas, nevertheless, some are already impacted by overfishing, tourism (Giglio et al. 2018) and by coral bleaching events associated to thermal anomalies (Ferreira et al. 2013; Gaspar et al. 2021). These phenomena jeopardize reef biodiversity, and ecosystem functions and services (Hughes et al. 2018a; Williams and Graham 2019). However, an understanding of temporal patterns in ecosystem functions of oceanic islands is still lacking. Here, we used the functional approach to investigate the temporal dynamics (2013-2019) of the reef benthic community in the most pristine reef in Brazil, Rocas Atoll. To date, this is the longest publicly available dataset for benthic communities in the Southwestern Atlantic, representing a baseline for future studies of dynamics and functional diversity from reef benthic communities.

\section{Material And Methods}

\section{Study area}

Rocas Atoll $\left(03^{\circ} 50^{\prime} \mathrm{S}, 33^{\circ} 49^{\prime} \mathrm{W}\right)$ is located approximately $267 \mathrm{~km}$ off the Brazilian coast (Kikuchi and Leão 1997). It is considered one of the world's smallest atolls, with $3,7 \mathrm{~km}$ in E-W directions and $2,5 \mathrm{~km}$ in N-S (Soares et al. 2011), and the only atoll in the South Atlantic Ocean (Kikuchi and Leão, 1997). Crustose coralline algae (CCA), vermetid gastropods and foraminiferans are the main shallow reef builders, while 
framework structure (Gherardi 1995; Kikuchi and Leão 1997). Rocas Atoll is the first Brazilian no-take marine reserve, established in 1979. It has controlled anthropic impacts (e.g. very low pollution and fishing) and it is probably the most similar to a pristine reef in Brazil, being a natural laboratory and an important study area (Longo et al. 2015).

\section{Benthic community sampling}

Reef benthic community was annually monitored from 2013 to 2019 (May and June). In each year, benthic data was collected by photoquadrat method in four different sites: Âncoras, Cemitério, Falsa Barreta and Podes Crer (Fig. 1). Every year, three $20 \mathrm{~m}$ transect were fixed at each site, and a $1 \mathrm{~m}^{2}$ quadrat was photographed every $2 \mathrm{~m}$ along each transect. In summary, over 838 photoquadrats were taken from the same reef area across seven years (Table 1 in Appendix). Percent cover of each photoquadrat were analyzed with CPCe software (Kohler and Gill 2006), randomly distributing 50 points over each photo. The organisms below each point were identified to the lowest taxonomic level possible.

Table 1

Reef sites and field effort in Rocas Atoll.

\begin{tabular}{|c|c|c|c|c|c|c|c|c|c|c|}
\hline & & & Photc & uadrat & & & & & & \\
\hline Site & Lat/Long & Depth & 2013 & 2014 & 2015 & 2016 & 2017 & 2018 & 2019 & Total \\
\hline Âncoras & $\begin{array}{l}03^{\circ} 52^{\prime} 51^{\prime \prime} \mathrm{S} \\
33^{\circ} 48^{\prime} 16^{\prime \prime} \\
\mathrm{W}\end{array}$ & $2-3 m$ & 28 & 32 & 30 & 33 & 30 & 33 & 31 & 217 \\
\hline Cemitério & $\begin{array}{l}03^{\circ} 52^{\prime} 18^{\prime \prime} \mathrm{S} \\
33^{\circ} 49^{\prime} 02^{\prime \prime} \\
\text { W }\end{array}$ & $1-2 m$ & 29 & 33 & 30 & 31 & 29 & 33 & 33 & 218 \\
\hline $\begin{array}{l}\text { Falsa } \\
\text { Barreta }\end{array}$ & $\begin{array}{l}03^{\circ} 51^{\prime} 64^{\prime \prime} \mathrm{S} \\
33^{\circ} 49^{\prime} 40^{\prime \prime} \\
\mathrm{W}\end{array}$ & $1-4 m$ & 30 & 33 & 30 & 32 & 30 & 33 & 30 & 218 \\
\hline $\begin{array}{l}\text { Podes } \\
\text { Crer }\end{array}$ & $\begin{array}{l}03^{\circ} 52^{\prime} 20^{\prime \prime} \mathrm{S} \\
33^{\circ} 48^{\prime} 45^{\prime \prime} \mathrm{W}\end{array}$ & $1-3 m$ & 30 & 32 & 30 & 32 & 30 & 31 & - & 185 \\
\hline Total per y & & & 117 & 130 & 120 & 128 & 119 & 130 & 94 & 838 \\
\hline
\end{tabular}

Functional traits

We selected six traits proposed by Aued et al (in prep) for the benthic communities from the Brazilian

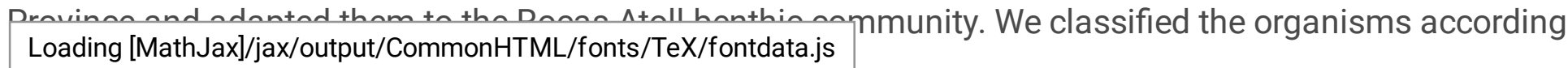


to five biological and one life history trait available in the literature (Table 2). Organisms sharing the same traits were grouped into Functional Entities (FE).

Table 2

Traits classification for reef benthic communities adapted from Aued et al (in prep).

\begin{tabular}{|c|c|c|c|}
\hline $\begin{array}{l}\text { Trait } \\
\text { category }\end{array}$ & Trait & Trait level & Description \\
\hline \multirow[t]{18}{*}{ Biological } & \multirow{4}{*}{$\begin{array}{l}\text { Maximum } \\
\text { body size }\end{array}$} & Small $(<10 \mathrm{~cm})$ & \multirow{4}{*}{$\begin{array}{l}\text { Related directly to substrate cover } \\
\text { (Woodward et al. 2005). For colonial } \\
\text { morphospecies, we used the maximum size } \\
\text { for colony or modular aggregations, and for } \\
\text { unitary morphospecies, the individual size. }\end{array}$} \\
\hline & & Medium (10-50cm) & \\
\hline & & Large $(50-400 \mathrm{~cm})$ & \\
\hline & & Very large $(>400 \mathrm{~cm})$ & \\
\hline & \multirow[t]{5}{*}{ Growth form } & Bushy & \multirow{5}{*}{$\begin{array}{l}\text { The growth form of benthic organisms is } \\
\text { related to the tridimensional habitat } \\
\text { complexity and use of resources (Richardson } \\
\text { et al. 2017). }\end{array}$} \\
\hline & & Encrusting & \\
\hline & & Encrusting/filamentous & \\
\hline & & Filamentous & \\
\hline & & Massive & \\
\hline & \multirow[t]{5}{*}{ Trophic type } & Autotroph & \multirow{5}{*}{$\begin{array}{l}\text { Trophic type corresponds to food web } \\
\text { interactions, competition and nutrient cycling } \\
\text { (Wahl et al. 2011). }\end{array}$} \\
\hline & & Autotroph/carnivore & \\
\hline & & Carnivore & \\
\hline & & Grazer & \\
\hline & & $\begin{array}{l}\text { Suspension/filter } \\
\text { feeder }\end{array}$ & \\
\hline & \multirow[t]{2}{*}{ Modularity } & Solitary & \multirow{2}{*}{$\begin{array}{l}\text { Associated to reproduction type and the } \\
\text { organisms' ability to occupy the substrate } \\
\text { (Wahl et al. 2011) }\end{array}$} \\
\hline & & Modular & \\
\hline & \multirow[t]{2}{*}{$\begin{array}{l}\text { Carbonate } \\
\text { accretion }\end{array}$} & Produce $\mathrm{CaCO}_{3}$ & \multirow{2}{*}{$\begin{array}{l}\text { Influences the potential for reef structure } \\
\text { development and maintenance (Perry and } \\
\text { Alvarez-Filip 2018). }\end{array}$} \\
\hline & & Do not produce $\mathrm{CaCO}_{3}$ & \\
\hline \multirow{3}{*}{$\begin{array}{l}\text { Life } \\
\text { history }\end{array}$} & \multirow{3}{*}{$\begin{array}{l}\text { Reproduction } \\
\text { type }\end{array}$} & Asexual & \multirow{3}{*}{$\begin{array}{l}\text { Can describe the ability to disperse and } \\
\text { recover after a disturbance, the persistence } \\
\text { and longevity of populations through time } \\
\text { (Costello et al. 2015) }\end{array}$} \\
\hline & & Sexual/asexual & \\
\hline & & Sexual & \\
\hline
\end{tabular}

Functional diversity indices and data analysis

We measured functional diversity indices (Functional Richness and Functional Entropy - Rao) for each year. Functional Richness (Fric) measures the convex hull volume occupied by functional entities in Loading [MathJax]/jax/output/CommonHTML/fonts/TeX/fontdata.js 
functional space. Fric can show how functional diversity is related to ecosystem function through the gain or loss of functional entities and their traits, without considering their abundances (Cornwell et al. 2006; Villéger et al. 2008). Functional Entropy (Fent) or Rao index represents a combination between species abundances and their functional dissimilarity (Mouillot et al. 2013). It is the sum of pairwise distances between species randomly chosen, weighted by their relative abundances (Botta-Dukát 2005), as defined by the mathematical formula:

$$
Q=\sum_{i} p_{i} K_{i}=\sum_{i} p_{i} \sum_{j} p_{j} \delta_{i j}
$$

where $p_{i}(i=1,2, \ldots, N)$ are species relative abundances in the community composed by $N$ species $\left(0<p_{i} \leq\right.$ 1 , because all calculations must involve only species with nonzero abundances); $\delta \mathrm{ij}$ are the elements of the dissimilarity matrix which summarize the pairwise functional dissimilarities between species $i$ and $j . K_{i}$ $=\sum_{\mathrm{j}} \mathrm{p}_{\mathrm{j}} \delta \mathrm{ij}$ represents the expected dissimilarity between species $\mathrm{i}$ and the randomly chosen species $\mathrm{j}$. When FEnt value approaches to 0 , it indicates dissimilar abundances distribution among the most unique functional entities (i.e. those located at functional space vertices). Higher FEnt values near 1 indicate a more even distribution in unique functional entities abundances.

Using a functional trait matrix built with Gower's distance, we plotted the multidimensional trait space for each year based on a Principal Coordinate Analysis (PCOA). The distribution of functional entities (FE) and their abundance were plotted in the functional trait space using the two principal axes. All analysis were made using software R (R Core Team, 2019). FRic was calculated using the function 'multidimFD' from 'FD' package (Laliberté et al. 2015), and for FEnt we used 'uniqueness' function (Ricotta et al. 2016). We used generalized linear models (GLM) with indices results and years as factors to test changes through the time series, and the package 'ggplot2' (Wickham and Winston 2019) for plots.

\section{Results}

\section{Community functional structure}

We identified 48 organisms grouped into 17 functional entities (those who share the same trait combination), considering the seven years of sampling. Functional entities and their respective ecosystem functions are presented in Fig. 2. Suspension/filter feeders are functional entities composed by sponges or ascidians, responsible for nutrient cycling function. Macroalgae make up primary production and high tridimensional complexity functional entities, while turf algae, cyanobacteria and zoanthids compose low tridimensional complexity functional entities. Corals such as Siderastrea stellata, Porites astreoides and Favia gravida (massive bioconstructors), and crustose coralline algae (encrusting bioconstructors), perform calcium carbonate accretion function, being responsible for reef formation and maintenance. The functional trait space was occupied by 15 functional entities every year, but organism's composition differed, reaching the highest value (36 morphospecies) in 2013 and the lowest (26 morphospecies) in 2019 (Table 3). 
Table 3

Number of morphospecies, functional entities (i.e.

morphospecies that share similar traits).

\begin{tabular}{|lll|}
\hline & Morphospecies richness & Functional entities \\
\hline 2013 & 36 & 15 \\
\hline 2014 & 31 & 15 \\
\hline 2015 & 33 & 15 \\
\hline 2016 & 28 & 15 \\
\hline 2017 & 30 & 15 \\
\hline 2018 & 29 & 15 \\
\hline 2019 & 26 & 15 \\
\hline
\end{tabular}

Low tridimensional complexity function, represented mainly by turf algae, was dominant every year, with functional entities mean percent cover oscillating from 40.56-59.18\% (GLM p <0.05) (Fig. 3). Despite presenting $5.96 \%$ cover in 2019 , high tridimensional complexity entities oscillated from $16.05-30.28 \%$ cover between 2013 and 2018 (GLM p < 0.05). Encrusting calcifiers also presented significant variations in percent cover (GLM $p<0.05)$, ranging from $1.96-5.47 \%$, while massive calcifiers did not have clear oscillations through years (GLM p >0.05), with abundances fluctuating between $1.65 \%$ and $2.70 \%$. Mean percent cover of suspension/filter-feeders did not exceed $1 \%$ nor presented clear oscillation over the years (GLM p >0.05).

\section{Functional diversity dynamics}

Overall, Functional Richness (FRic) oscillated over the years (GLM p <0.05) but presented small changes in convex hull volumes over the years (Fig. 4), indicating temporal stability in ecosystem functions provided by functional entities. FRic is shown in the functional space, where axes represent the higher explanation PCoA axis (PC1-PC2). Temporal differences in FRic occurred due to the presence of a massive bioconstructor functional entity (represented by Favia gravida) only in 2015 and 2017; and a high tridimensional primary producer functional entity in 2013, 2014 and 2016 (Fig. 4). Despite an almost fulfilled convex hull volume in 2018 , due to a new functional entity composed by a globular suspension/filter-feeder, that did not appear in previous years, FRic was lower than 2015 and 2017 because the convex hull volume was less fulfilled in axis 3 and 4 (Fig. 5 in Appendix).

Functional Entropy (FEnt) was low every year, indicating uneven percent cover between functional entities (Fig. 6). Despite significant oscillations in FEnt between years (GLM $p<0.05)$, differences among years occurred in small scales (Fig. 6), showing small variations in percent cover of functional entities with unique trait combination. These fluctuations in FEnt were conducted by low and high tridimensional 
vertices. The highest FEnt was in 2013, representing a well-distributed percent cover of extreme functional entities if compared to other years, while the lowest was in 2019, due to uneven percent cover distribution, when reef benthic community was dominated by low tridimensional complexity functional entities represented mainly by turf algae ( $59.19 \%$ cover; Fig. 3$)$.

\section{Discussion}

Our study is the first to use functional approach in a temporal scale for reef benthic communities. Our results show that Rocas Atoll benthic community is temporally dominated by functional entities responsible for providing low reef tridimensional complexity (e.g. turf algae, cyanobacteria and Zoanthus sociatus), high tridimensional complexity and primary production (e.g. macroalgae as Sargassum spp., Dictyopteris spp.), with low contribution of carbonate accretion (e.g. crustose coralline algae and corals as Siderastrea stellata, Porites astreoides and Favia gravida) and nutrient cycling (e.g. sponges and/or ascidians) functional entities. This dominance reflected in low values of functional entropy (FEnt), due to uneven abundances distribution between unique functional entities, that is, those that have unique trait combination and are in functional space vertices. Functional richness (FRic) oscillated over years, but did not show great changes in functional spaces, maintaining an equity in the number of functional entities and indicating stability of reef functions in Rocas Atoll, even with unequal abundances' distribution.

Diversity patterns in Brazilian oceanic islands are well known for reef fishes assemblages and barely known for benthic organisms (Floeter and Gasparini 2000; Floeter et al. 2001, 2008; Pinheiro et al. 2017, Aued et al. 2018). Marine oceanic communities generally present low species richness when compared to coastal communities, specially due to their isolation and different oceanographic conditions (Pinheiro et al. 2017), and functional richness (FRic) usually responds to species richness pattern (Whittaker et al. 2014; Jacquet et al. 2017; Wong et al. 2018). Our results indicate that organisms' richness did not affect the number of functional entities and FRic values, which presented small variations through the years. In 2013, when we identified 36 morphospecies, and in 2019 - the lowest morphospecies richness -, FRic was the same in our temporal series. If compared to other regions in the Brazilian province - mainly those located at mid-latitudes, but also with Fernando de Noronha Archipelago, other oceanic island located less than 100 miles from Rocas Atoll -, the number of taxa and FRic are both low (Aued et al. 2018; Aued et al. in prep).

Low tridimensional complexity functional entities are composed by benthic organisms from different groups, such as epilithic algal matrix, articulate coralline algae, cyanobacteria and zoanthids. Different from entities that are bioconstructors or provide high tridimensional complexity, they form widespread patches and occupy larger areas on the substrate, with small vertical growth. Epilithic algal matrix (EAM or turf algae) is the main component of reef benthic communities among Brazilian reefs, including Rocas Atoll (Longo et al. 2015; Aued et al. 2018). Our results showed higher abundances of low tridimensional complexity functional entities every year, indicating that the community is also dominated temporally by turf. On EAM composition, it is possible to find a variety of algal groups (e.g. diatoms, cyanobacteria, 
contribute to sediment trap, primary productivity, and provide habitat and food for other marine organisms (Vroom et al. 2006; Dijkstra et al. 2017), but offer smaller tridimensional complexity. Therefore, due to its high percent cover, the functional entities composed by EAM are also the main responsible for primary production in Rocas Atoll.

High tridimensional complexity in marine environments, such as tropical forests in terrestrial environments, provides habitat for many marine species, promotes interactions between species and the environment (Marx and Herrkind 1985; Williams et al. 2002; Graham and Nash 2013; Richardson et al. 2017; Fulton et al. 2019; Lamy et al. 2020), and also influences reef fish recruitment and development (Evans et al. 2014; Fontoura et al. 2019). This function is generally associated to branching corals in the Caribbean and Indo-Pacific sites (Alvarez-Filip et al. 2011; McWilliam et al. 2018; Richardson et al. 2020), but for Rocas Atoll, due to the absence of branching bioconstructors, the 'high tridimensional complexity' is associated to macroalgae. Opposed to massive corals, like Siderastrea stellata, or benthic organisms that form widespread patches, like EAM and zoanthids, macroalgae can act as refuge from larger predators and affect the local diversity (Ware et al. 2019). Besides providing local tridimensional complexity, primary production is also a function performed by macroalgae and EAM (Brandl et al. 2019; Fulton et al. 2019). Primary producers usually dominate populated atolls and regions with high human disturbances (Sandin et al. 2008). Conversely, for Rocas Atoll, where anthropic impacts are controlled, primary production is associated to ten of the 17 functional entities found in our study. Entities associated to low and high tridimensional complexity occupy together around $80 \%$ of the substrate in every sampling year. Due to their dominance over the community and to their extreme trait combination, FEnt was low at Rocas Atoll every year, but still the small oscillations in FEnt occurred as a function of the oscillations of functional entities percent cover, indicating that these functional entities are substantially contributing to ecosystem functioning (D’Agata et al. 2016).

Both carbonate accretion (bioconstructors) and nutrient cycling (suspention/filder feeders) functional entities, have low percent cover at Brazilian Province when compared to the other groups (Aued et al. 2018), and our results showed that this has been a consistent pattern at Rocas Atoll through time. The distribution and abundance of bioconstructors can create habitat heterogeneity and provide the main framework of reef ecosystems (Perry and Alvarez-Filip 2018). FRic revealed four functional entities responsible by calcium carbonate accretion across time, but due to its unique trait combination and low percent cover, they might be considered as vulnerable functional entities. Crustose coralline algae (CCA) is the main reef builder in Rocas Atoll (Kikuchi and Leão 1997), but during the years of sampling it presented low and oscillating percent cover. This pattern may be related to a potential limitation of the photoquadrat method used (Preskitt et al. 2004). The same occurred to the functional entities composed by corals that act as massive bioconstructors. Still, the maintenance of massive bioconstructors percent cover indicates that calcium carbonate accretion function is stable over the years. Sponges and/or ascidians (suspension/filter feeder functional entities) are the main responsible by nutrient uptake and cycling, and bioerosion in reef ecosystems (Bell 2008; Brandl et al. 2019). Although suspension/filter feeders were persistent, their percent cover was extremely low. Even providing important functional roles in the 
ecosystem (Bell 2008; De Goeij et al. 2013), due to its low percent cover, suspension/filter feeders might not be considerably influencing the nutrient cycling in Rocas Atoll shallow reefs.

Functional richness and functional entropy are indices that represent the actual state of communities functional structure (Galland et al. 2020). Therefore, applying them in temporal scales might act as a baseline for future studies. Our results indicated a temporal stability in Rocas Atoll benthic communities, in the opposite way of many places around the world, where not just benthic, but also fish communities, are eroding (Jackson 2001; Gardner et al. 2003; Schutte et al. 2010; Alvarez-Filip et al. 2011; Cruz et al. 2015a; Smith et al. 2016; de Bakker et al. 2017; Leggat et al. 2019; Muñiz-Castillo et al. 2019). Changes in FRic over the years occurred when two specific functional entities, a massive bioconstructor and a suspension/filter feeder, were found in our analysis. Higher FRic values were in 2015 and 2017, when the massive bioconstructors functional entity appeared in one photoquadrat in both years, while in 2018 - the second higher FRic -, the suspension/filter feeder was detected. In the other years, when both functional entities were not found in our analysis, FRic in Rocas Atoll presented the lowest values, but no ecosystem function was lost.

FEnt was low every year due to uneven abundances distribution between functional entities with unique trait combination (i.e. those located at functional space vertices). The uneven abundance distribution over the years is conduced manly by the dominance of functional entities responsible for low and high tridimensional complexity, and low percent cover of other groups as bioconstructors and suspension/filter-feeders, a pattern already observed for Brazilian Province and Rocas Atoll (Longo et al. 2015; Aued et al. 2018). Oscillations in FEnt are, therefore, related to these dominant groups and their ephemeral oscillations, given that they are groups that respond faster to different environmental conditions (Cheroske et al. 2000; Vroom et al. 2006). By using both FRic and FEnt, it is possible to have a notion of communities functional redundancy (Galland et al. 2020). Functional redundancy buffers ecosystems functions loss against species loss in a community, ensuring stability and resilience to communities structures and functions (Bender et al. 2017; Biggs et al. 2020). FEnt low values and high FRic over the years might be indicating low functional redundancy, that is, there are many functional entities with unique trait combination with low percent cover in Rocas Atoll benthic community. If somehow these functional entities and morphospecies go extinct locally, considering all impacts that might happen with climate change over benthic communities (i.e. phase shifts, reef flattening) (AlvarezFilip et al. 2011; de Bakker et al. 2017; McWilliam et al. 2020), there will be no other functional entities able to substitute the same function in the functional space and, consequentially, there will be erosion in ecosystems functions (Wong et al. 2018).

Species occurrence and abundances can vary in different ways in a community, depending on natural changes of environmental conditions such as light penetration, temperature and sediment (Putman and Wratten 1984; Perry and Alvarez-Filip 2018). Consequently, changes on environmental conditions can cause impacts in species traits and abundances and, therefore, in ecosystem functions (Wong et al. 2018; Zawada et al. 2019a). Being an oceanic island, Rocas Atoll is a very dynamic system (Longo et al. 2015), with intanco unatar nirmulation and wave antinn that nan influence the availability and sediment dynamics Loading [MathJax]/jax/output/CommonHTML/fonts/TeX/fontdata.js 
(Hearn et al. 2001). For example, depending on the quantity of sediment, it can cause shading and hence, affect primary production (Riul et al. 2008), also it can promote the temporal burrowing and smothering of coral colonies (Brown et al. 2002). This probably explains differences in percent cover of massive bioconstructors functional entities. The intense hydrodynamic at shallow tide pools can also favor the presence of more resistant functional entities (Steneck and Dethier 1994; Cheroske et al. 2000), such as the ones composed by epilithic algal matrix, macroalgae and crustose coralline algae.

Considering the more common and frequent global impacts caused by ocean warming and thermal anomalies, and other emerging impacts of the Anthropocene (Hughes et al. 2017, 2018b; Lough et al. 2018; Perry and Alvarez-Filip 2018; Williams et al. 2019), there is a chance of Rocas Atoll be impacted either. In view of these changes around the world, it is more than necessary to enhance our knowledge of ecosystems actual state to serve as baselines for future studies (Christensen et al. 1996; Sandin et al. 2008; Downs et al. 2011; Gatti et al. 2015; Chollett and Robertson 2020), as well as to keep monitoring these communities structures and functions (Alvarez-Filip et al. 2011; Cruz et al. 2015b; Heron et al. 2016; Smith et al. 2016; de Bakker et al. 2017). Our study, inserted in Long Term Ecological Research of Brazilian Oceanic Islands, therefore acts as a baseline for Brazilian Province, since it provides the actual state of reef benthic communities using a functional approach, in an environment with no direct anthropic impacts.

Wilderness areas as Rocas Atoll support unique ecological values, different from the ones near the coast, due to well-managed efforts and limited human pressure, being the only environment considered as near pristine in Brazil (Longo et al. 2015). In our research, due to the maintenance in number of functional entities, small oscillations in FRic and FEnt, ecosystem functions do not seem to vary substantially, indicating a stable state dominated by primary producers and tridimensional complexity functional entities over the years. However, we speculate that the changes in the Anthropocene may result in gains in some functions (e.g. low complexity) and loss of other functions (e.g. carbonate accretion), and hence cause erosions in FRic and even smaller FEnt values. Indeed, a strong bleaching event has stricken Rocas Atoll bioconstructors recently (Gaspar et al. 2021). Therefore, reef communities are expected to show changes in the next years. Although COVID-19 pandemic and political dismantling of science and institutions in Brazil are impairing our monitoring, the continuity of temporal sampling is needed to understand how local and global variables are affecting benthic ecosystem functions even at pristine places, like Rocas Atoll. This can help to predict the effects on some ecosystem function (e.g. complexity) caused by global changes and it's consequence for the ecosystem services.

\section{Declarations}

\section{Acknowledgements}

We would like to thank the Instituto Chico Mendes de Conservação da Biodiversidade (ICMBIO, Environment Ministry), which provided sampling permit for Rocas Atoll Reserve (license number 58324-9). We also thank LTER - Brazilian Oceanic Islands (PELD-ILOC - CNPq 441241/2016-6 to CELF) and all the Loading [MathJax]/jax/output/CommonHTML/fonts/TeX/fontdata.js sults. To Ecology Graduate Program, from 
Federal University of Santa Catarina, for all the structure provided to the authors; to Coordenação de Aperfeiçoamento de Pessoal de Nível Superior (CAPES) and Conselho Nacional de Desenvolvimento Científico e Tecnológico (CNPQ) for the financial support. LCPMS was supported by a post-doctoral grant awarded by CAPES - Brazil. We specially thank Maurizélia "Zelinha" de Brito and Jarian Dantas for all the support, teachings and guidance during LTER expeditions to Rocas Atoll.

\section{Funding}

This work was supported by the research program "Programa de Monitoramento de Longa Duração das Comunidades Recifais de llhas Oceânicas - PELD ILOC" (CNPq 441241/2016-6 to CELF). AWA received a post-doctoral fellowship from CNPq/CAPES/FAPs/BC-Fundo Newton - Pesquisa Ecológica de Longa Duração (CNPQ-CAPES-PELD).

\section{Conflicts of interest}

The authors declare that they have no conflict of interest.

\section{Availability of data and material}

All data generated and analyzed during this study are available from the corresponding author. The LTER program will publish all data on a global database soon.

\section{Code availability}

The code used for the analysis are available from the corresponding author.

\section{Author's contributions}

VAPP, AWA and BS: substantial contribution to the concept and design of the study; contribution to data collection; contribution to data analysis and interpretation; contribution to the manuscript's preparation.

JBZ and LCPMS: contribution to data analysis; contribution to the manuscript's preparation.

\section{References}

1. Alvarez-Filip L, Dulvy NK, Gill JA, Côté IM, Watkinson AR (2009) Flattening of Caribbean coral reefs: Region-wide declines in architectural complexity. Proc R Soc B Biol Sci 276:3019-3025. doi:10.1098/rspb.2009.0339

2. Alvarez-Filip L, Gill JA, Dulvy NK, Perry AL, Watkinson AR, Côté IM (2011) Drivers of region-wide declines in architectural complexity on Caribbean reefs. Coral Reefs 30:1051-1060. doi:10.1007/s00338-011-0795-6

3. Aued AW, Smith F, Quimbayo JP, Cândido DV, Longo GO, Ferreira CEL, Witman JD, Floeter SR, Segal B (2018) Large-scale patterns of benthic marine communities in the Brazilian Province. PLoS One 1- 
4. Bejarano S, Jouffray JB, Chollett I, Allen R, Roff G, Marshell A, Steneck R, Ferse SCA, Mumby PJ (2017) The shape of success in a turbulent world: wave exposure filtering of coral reef herbivory. Funct Ecol 31:1312-1324. doi:10.1111/1365-2435.12828

5. Bell JJ (2008) The functional roles of marine sponges. Estuar Coast Shelf Sci 79:341-353. doi:10.1016/j.ecss.2008.05.002

6. Bellwood DR, Hughes TP, Folke C, Nyström M (2004) Confronting the coral reef crisis. Nature 429:827-833. doi:10.1038/nature02691

7. Bender MG, Leprieur F, Mouillot D, Kulbicki M, Parravicini V, Pie MR, Barneche DR, Oliveira-Santos LGR, Floeter SR (2017) Isolation drives taxonomic and functional nestedness in tropical reef fish faunas. Ecography 40:425-435. doi:10.1111/ecog.02293

8. Biggs CR, Yeager LA, Bolser DG, Bonsell C, Dichiera AM, Hou Z, Keyser SR, Khursigara AJ, Lu K, Muth AF, Negrete B, Erisman BE (2020) Does functional redundancy affect ecological stability and resilience? A review and meta-analysis. Ecosphere. doi:10.1002/ecs2.3184

9. Bolam SG, Mcllwaine PSO, Garcia C (2016) Application of biological traits to further our understanding of the impacts of dredged material disposal on benthic assemblages. Mar Pollut Bull 105:180-192. doi:10.1016/j.marpolbul.2016.02.031

10. Botta-Dukát Z (2005) Rao's quadratic entropy as a measure of functional diversity based on multiple traits. J Veg Sci 16:533-540. doi:10.1111/j.1654-1103.2005.tb02393.x

11. Brandl SJ, Rasher DB, Côté IM, Casey JM, Darling ES, Lefcheck JS, Duffy JE (2019) Coral reef ecosystem functioning: eight core processes and the role of biodiversity. Front Ecol Environ 445-454. doi:10.1002/fee.2088

12. Bremner J, Rogers S, Frid C (2003) Assessing functional diversity in marine benthic ecosystems: A comparison of approaches. Mar Ecol Prog Ser 254:11-25. doi:10.3354/meps254011

13. Bremner J, Rogers SI, Frid CLJ (2006) Methods for describing ecological functioning of marine benthic assemblages using biological traits analysis (BTA). Ecol Indic 6:609-622. doi:10.1016/j.ecolind.2005.08.026

14. Brown BE, Clarke KR, Warwick RM (2002) Serial patterns of biodiversity change in corals across shallow reef flats in KO Phuket, Thailand, due to the effects of local (sedimentation) and regional (climatic) perturbations. Mar Biol 141:21-29. doi:10.1007/s00227-002-0810-0

15. Cardinale BJ, Duffy JE, Gonzalez A, Hooper DU, Perrings C, Venail P, Narwani A, MacE GM, Tilman D, Wardle DA, Kinzig AP, Daily GC, Loreau M, Grace JB, Larigauderie A, Srivastava DS, Naeem S (2012) Biodiversity loss and its impact on humanity. Nature 486:59-67. doi:10.1038/nature11148

16. Cheroske AG, Williams SL, Carpenter RC (2000) Effects of physical and biological disturbances on algal turfs in Kaneohe Bay, Hawaii. J Exp Mar Bio Ecol 248:1-34. doi:10.1016/S00220981(00)00153-2

17. Chollett I, Robertson DR (2020) Comparing biodiversity databases: Greater Caribbean reef fishes as a case study. Fish Fish 21:1195-1212. doi:10.1111/faf.12497 
18. Christensen NL, Bartuska AM, Brown JH, Carpenter S, D’Antonio C, Francis R, Franklin JF, MacMahon JA, Noss RF, Parsons DJ, Peterson CH, Turner MG, Woodmansee RG (1996) The report of the ecological society of america committee on the scientific basis for ecosystem management. Ecol Appl 6:665-691. doi:10.2307/2269460

19. Connel JH (1978) Diversity in Tropical Rain Forests and Coral Reefs. Science 80-:199:1302-1310

20. Connell SD, Foster MS, Airoldi L (2014) What are algal turfs? Towards a better description of turfs. Mar Ecol Prog Ser 495:299-307. doi:10.3354/meps10513

21. Contreras-Silva Al, Tilstra A, Migani V, Thiel A, Pérez-Cervantes E, Estrada-Saldívar N, Elias-llosvay X, Mott C, Alvarez-Filip L, Wild C (2020) A meta-analysis to assess long-term spatiotemporal changes of benthic coral and macroalgae cover in the Mexican Caribbean. Sci Rep 10:1-12. doi:10.1038/s41598-020-65801-8

22. Cornwell WK, Scwilk DW, Ackerly DD (2006) A Trait-Based Test for Habitat Filtering: Convex Hull Volume. Ecology 87:1465-1471 i: 10.1890/0012-9658(2006)87[1465:ATTFHF]2.0.C0;2 ) :. do

23. Costanza R, D’Arge R, de Groot R, Farber S, Grasso M, Hannon B, Limburg K, Naeem S, O’Neill RV, Paruelo J, Raskin RG, Sutton P, van den Belt M (1997) The value of the world's ecosystem services and natural capital. Nature 387:253-260. doi:10.1038/387253a0

24. Côté IM, Gill JA, Gardner TA, Watkinson AR (2005) Measuring coral reef decline through metaanalyses. Philos Trans R Soc B Biol Sci 360:385-395. doi:10.1098/rstb.2004.1591

25. Cruz ICS, Loiola M, Albuquerque T, Reis R, De J (2015a) Effect of Phase Shift from Corals to Zoantharia on Reef Fish Assemblages. PLoS One 1-16. doi:10.1371/journal.pone.0116944

26. Cruz ICS, Kikuchi RKP, De, Longo LL, Creed JC (2015b) Evidence of a phase shift to Epizoanthus gabrieli Carlgreen, 1951 (Order Zoanthidea) and loss of coral cover on reefs in the Southwest Atlantic. Mar Ecol 1951:318-325. doi:10.1111/maec.12141

27. D’Agata S, Mouillot D, Wantiez L, Friedlander AM, Kulbicki M, Vigliola L (2016) Marine reserves lag behind wilderness in the conservation of key functional roles. Nat Commun doi.

$10.1038 /$ ncomms 12000

28. Darling ES, Alvarez-Filip L, Oliver TA, Mcclanahan TR, Côté IM (2012) Evaluating life-history strategies of reef corals from species traits. Ecol Lett 15:1378-1386. doi:10.1111/j.1461-0248.2012.01861.x

29. de Bakker DM, van Duyl FC, Bak RPM, Nugues MM, Nieuwland G, Meesters EH (2017) 40 Years of benthic community change on the Caribbean reefs of Curaçao and Bonaire: the rise of slimy cyanobacterial mats. Coral Reefs 36:355-367. doi:10.1007/s00338-016-1534-9

30. De Goeij JM, Van Oevelen D, Vermeij MJA, Osinga R, Middelburg JJ, De Goeij AFPM, Admiraal W (2013) Surviving in a marine desert: The sponge loop retains resources within coral reefs. Science 342:108-110. doi:10.1126/science.1241981

31. Denis V, Ribas-Deulofeu L, Sturaro N, Kuo CY, Chen CA (2017) A functional approach to the structural complexity of coral assemblages based on colony morphological features. Sci Rep 7:1-11. doi:10.1038/s41598-017-10334-w 
32. Denis V, Chen JW, Chen Q, Hsieh YE, Lin YV, Wang CW, Wang HY, Sturaro N (2019) Biogeography of functional trait diversity in the Taiwanese reef fish fauna. Ecol Evol 9:522-532.

doi:10.1002/ece3.4771

33. Dijkstra JA, Harris LG, Mello K, Litterer A, Wells C, Ware C (2017) Invasive seaweeds transform habitat structure and increase biodiversity of associated species. J Ecol 105:1668-1678. doi:10.1111/13652745.12775

34. Downs PW, Singer MS, Orr BK, Diggory ZE, Church TC (2011) Restoring ecological integrity in highly regulated rivers: The role of baseline data and analytical references. Environ Manage 48:847-864. doi:10.1007/s00267-011-9736-y

35. Ernst R, Linsenmair KE, Rödel MO (2006) Diversity erosion beyond the species level: Dramatic loss of functional diversity after selective logging in two tropical amphibian communities. Biol Conserv 133:143-155. doi:10.1016/j.biocon.2006.05.028

36. Evans RD, Wilson SK, Field SN, Moore JAY (2014) Importance of macroalgal fields as coral reef fish nursery habitat in north-west Australia. Mar Biol 161:599-607. doi:10.1007/s00227-013-2362-x

37. Ferreira BP, Costa MBSF, Coxey MS, Gaspar ALB, Veleda D, Araujo M (2013) The effects of sea surface temperature anomalies on oceanic coral reef systems in the southwestern tropical Atlantic. Coral Reefs 32:441-454. doi:10.1007/s00338-012-0992-y

38. Floeter SR, Gasparini JL (2000) The southwestern Atlantic reef fish fauna: Composition and zoogeographic patterns. J Fish Biol 56:1099-1114. doi:10.1006/jfbi.2000.1231

39. Floeter SR, Guimarães RZP, Rocha LA, Ferreira CEL, Rangel CA, Gasparini JL (2001) Geographic variation in reef-fish assemblages along the Brazilian coast. Glob Ecol Biogeogr 10:423-431. doi:10.1046/j.1466-822X.2001.00245.x

40. Floeter SR, Rocha LA, Robertson DR, Joyeux JC (2008) Atlantic reef fish biogeography and evolution. 22-47. doi: 10.1111/j.1365-2699.2007.01790.x

41. Fontoura L, Zawada KJA, D'agata S, Álvarez-Noriega M, Baird AH, Boutros N, Dornelas M, Luiz OJ, Madin JS, Maina JM, Pizarro O, Torres-Pulliza D, Woods RM, Madin EMP (2019) Climate-driven shift in coral morphological structure predicts decline of juvenile reef fishes. Glob Chang Biol gcb.14911. doi:10.1111/gcb.14911

42. Fulton CJ, Abesamis RA, Berkström C, Depczynski M, Graham NAJ, Holmes TH, Kulbicki M, Noble MM, Radford BT, Tano S, Tinkler P, Wernberg T, Wilson SK (2019) Form and function of tropical macroalgal reefs in the Anthropocene. Funct Ecol 0-3. doi:10.1111/1365-2435.13282

43. Galland T, Pérez Carmona C, Götzenberger L, Valencia E, de Bello F (2020) Are redundancy indices redundant? An evaluation based on parameterized simulations. Ecol Indic 116:106488. doi:10.1016/j.ecolind.2020.106488

44. Gardner TA, Côté IM, Gill JA, Grant A, Watkinson AR (2003) Long-term region-wide declines in Caribbean corals. Science 301:958-960. doi:10.1126/science.1086050

45. Gaspar TL, Quimbayo JP, Ozekoski R, Nunes LT, Aued AW, Mendes TC, Garrido AG, Segal B (2021) 
sequential Marine Heatwaves. Biota Neotrop 21:95-97. doi:10.1590/1676-0611-bn-2020-1131

46. Gatti G, Bianchi CN, Parravicini V, Rovere A, Peirano A, Montefalcone M, Massa F, Morri C (2015) Ecological change, sliding baselines and the importance of historical data: Lessons from combing observational and quantitative data on a temperate reef over 70 years. PLoS One 10:1-20. doi:10.1371/journal.pone.0118581

47. Gherardi DFM (1995) A windward coralline algal ridge on Rocas Atoll, Atlantic Ocean. Coral Reefs 14:34. doi:10.1007/BF00304069

48. Giglio VJ, Pinheiro HT, Bender MG, Bonaldo RM, Costa-Lotufo LV, Ferreira CEL, Floeter SR, Freire A, Gasparini JL, Joyeux JC, Krajewski JP, Lindner A, Longo GO, Lotufo TMC, Loyola R, Luiz OJ, Macieira RM, Magris RA, Mello TJ, Quimbayo JP, Rocha LA, Segal B, Teixeira JB, Vila-Nova DA, Vilar CC, Zilberberg C, Francini-Filho RB (2018) Large and remote marine protected areas in the South Atlantic Ocean are flawed and raise concerns: Comments on Soares and Lucas (2018). Mar Policy 96:13-17. doi: 10.1016/j.marpol.2018.07.017

49. Graham NAJ, Nash KL (2013) The importance of structural complexity in coral reef ecosystems. Coral Reefs 32:315-326. doi:10.1007/s00338-012-0984-y

50. Gusmao JB, Brauko KM, Eriksson BK, Lana PC (2016) Functional diversity of macrobenthic assemblages decreases in response to sewage discharges. Ecol Indic 66:65-75. doi:10.1016/j.ecolind.2016.01.003

51. Halpern BS, Floeter SR (2008) Functional diversity responses to changing species richness in reef fish communities. Mar Ecol Prog Ser 364:147-156. doi:10.3354/meps07553

52. Halpern BS, Walbridge S, Selkoe KA, Kappel CV, Micheli F, D’Agrosa C, Bruno JF, Casey KS, Ebert C, Fox HE, Fujita R, Heinemann D, Lenihan HS, Madin EMP, Perry MT, Selig ER, Spalding M, Steneck R, Watson R (2008) A global map of human impact on marine ecosystems. Science 319:948-952

53. Hearn C, Atkinson M, Falter J (2001) A physical derivation of nutrient-uptake rates in coral reefs: Effects of roughness and waves. Coral Reefs 20:347-356. doi:10.1007/s00338-001-0185-6

54. Heron SF, Maynard JA, Van Hooidonk R, Eakin CM (2016) Warming Trends and Bleaching Stress of the World's Coral Reefs 1985-2012. Sci Rep 6:1-14. doi:10.1038/srep38402

55. Hughes TP, Graham NAJ, Jackson JBC, Mumby PJ, Steneck RS (2010) Rising to the challenge of sustaining coral reef resilience. Trends Ecol Evol 25:633-642. doi:10.1016/j.tree.2010.07.011

56. Hughes TP, Kerry JT, Álvarez-Noriega M, Álvarez-Romero JG, Anderson KD, Baird AH, Babcock RC, Beger M, Bellwood DR, Berkelmans R, Bridge TC, Butler IR, Byrne M, Cantin NE, Comeau S, Connolly SR, Cumming GS, Dalton SJ, Diaz-Pulido G, Eakin CM, Figueira WF, Gilmour JP, Harrison HB, Heron SF, Hoey AS, Hobbs JPA, Hoogenboom MO, Kennedy EV, Kuo CY, Lough JM, Lowe RJ, Liu G, McCulloch MT, Malcolm HA, McWilliam MJ, Pandolfi JM, Pears RJ, Pratchett MS, Schoepf V, Simpson T, Skirving WJ, Sommer B, Torda G, Wachenfeld DR, Willis BL, Wilson SK (2017) Global warming and recurrent mass bleaching of corals. Nature 543:373-377. doi:10.1038/nature21707

57. Hughes TP, Kerry JT, Baird AH, Connolly SR, Dietzel A, Eakin CM, Heron SF, Hoey AS, Hoogenboom Mn I iu E MalMlilliam M I Dase D I Dratrhatt M Mc ckirving WJ, Stella JS, Torda G (2018a) Global Loading [MathJax]/jax/output/CommonHTML/fonts/TeX/fontdata.js 
warming transforms coral reef assemblages. Nature 556:492-496. doi:10.1038/s41586-018-0041-2

58. Hughes TP, Anderson KD, Connolly SR, Heron SF, Kerry JT, Lough JM, Baird AH, Baum JK, Berumen ML, Bridge TC, Claar DC, Eakin CM, Gilmour JP, Graham NAJ, Harrison H, Hobbs JPA, Hoey AS, Hoogenboom M, Lowe RJ, McCulloch MT, Pandolfi JM, Pratchett M, Schoepf V, Torda G, Wilson SK (2018b) Spatial and temporal patterns of mass bleaching of corals in the Anthropocene. Science 359:80-83. doi:10.1126/science.aan8048

59. Jackson JBC (2001) Historical Overfishing and the Recent Collapse of Coastal Ecosystems. Science 293:629-637. doi:10.1126/science.1059199

60. Jacquet C, Mouillot D, Kulbicki M, Gravel D (2017) Extensions of Island Biogeography Theory predict the scaling of functional trait composition with habitat area and isolation. Ecol Lett 20:135-146. doi:10.1111/ele.12716

61. Knowlton N, Jackson JBC (2008) Shifting baselines, local impacts, and global change on coral reefs. PLoS Biol 6:0215-0220. doi:10.1371/journal.pbio.0060054

62. Kohler KE, Gill SM (2006) Coral Point Count with Excel extensions (CPCe): A Visual Basic program for the determination of coral and substrate coverage using random point count methodology. Comput Geosci 32:1259-1269. doi:10.1016/j.cageo.2005.11.009

63. Laliberté E, Legendre P, Shipley B (2015) FD: measuring functional diversity from multiple traits, and other tools for functional ecology. R Packag Version 1:0-12

64. Lamy T, Koenigs C, Holbrook SJ, Miller RJ, Stier AC, Reed DC (2020) Foundation species promote community stability by increasing diversity in a giant kelp forest. Ecology. doi:10.1002/ecy.2987

65. Leão ZMAN, Kikuchi RKP, Oliveira MDM (2019) The Coral Reef Province of Brazil, Second Edi. Elsevier Ltd.

66. Leggat WP, Camp EF, Suggett DJ, Heron SF, Fordyce AJ, Gardner S, Deakin L, Turner M, Beeching LJ, Kuzhiumparambil U, Eakin CM, Ainsworth TD (2019) Rapid Coral Decay Is Associated with Marine Heatwave Mortality Events on Reefs. Curr Biol 1-8. doi:10.1016/j.cub.2019.06.077

67. Longo GO, Morais RA, Martins CDL, Mendes TC, Aued AW, Cândido DV, De Oliveira JC, Nunes LT, Fontoura L, Sissini MN, Teschima MM, Silva MB, Ramlov F, Gouvea LP, Ferreira CEL, Segal B, Horta PA, Floeter SR (2015) Between-habitat variation of benthic cover, reef fish assemblage and feeding pressure on the benthos at the only atoll in South Atlantic: Rocas atoll, NE Brazil. PLoS One 10:1-29. doi:10.1371/journal.pone.0127176

68. Lough JM, Anderson KD, Hughes TP (2018) Increasing thermal stress for tropical coral reefs: 18712017. Sci Rep 8:1-8. doi:10.1038/s41598-018-24530-9

69. Madin JS, Anderson KD, Andreasen MH, Bridge TCL, Cairns SD, Connolly SR, Darling ES, Diaz M, Falster DS, Franklin EC, Gates RD, Hoogenboom MO, Huang D, Keith SA, Kosnik MA, Kuo CY, Lough JM, Lovelock CE, Luiz O, Martinelli J, Mizerek T, Pandolfi JM, Pochon X, Pratchett MS, Putnam HM, Roberts TE, Stat M, Wallace CC, Widman E, Baird AH (2016) The Coral Trait Database, a curated database of trait information for coral species from the global oceans. Sci Data 3:1-22. 
70. Marx J, Herrkind W (1985) Macroalgae (Rhodophyta: Laurencia spp.) as habitat for young juvenile spiny lobsters, Panulirus argus. Bull Mar Sci 36:423-431

71. McWilliam M, Hoogenboom MO, Baird AH, Kuo C-Y, Madin JS, Hughes TP (2018) Biogeographical disparity in the functional diversity and redundancy of corals. Proc Natl Acad Sci 115:3084-3089. doi:10.1073/pnas.1716643115

72. McWilliam M, Pratchett MS, Hoogenboom MO, Hughes TP (2020) Deficits in functional trait diversity following recovery on coral reefs. Proc R Soc B Biol Sci 287:20192628. doi:10.1098/rspb.2019.2628

73. Mouillot D, Culioli JM, Pelletier D, Tomasini JA (2008) Do we protect biological originality in protected areas? A new index and an application to the Bonifacio Strait Natural Reserve. Biol Conserv 141:1569-1580. doi:10.1016/j.biocon.2008.04.002

74. Mouillot D, Graham NAJ, Villéger S, Mason NWH, Bellwood DR (2013) A functional approach reveals community responses to disturbances. Trends Ecol Evol 28:167-177. doi:10.1016/j.tree.2012.10.004

75. Mouillot D, Villeger S, Parravicini V, Kulbicki M, Arias-Gonzalez JE, Bender M, Chabanet P, Floeter SR, Friedlander A, Vigliola L, Bellwood DR (2014) Functional over-redundancy and high functional vulnerability in global fish faunas on tropical reefs. Proc Natl Acad Sci 111:13757-13762. doi:10.1073/pnas.1317625111

76. Munday PL, Jones GP, Pratchett MS, Williams AJ (2008) Climate change and the future for coral reef fishes. Fish Fish 9:261-285. doi:10.1111/j.1467-2979.2008.00281.x

77. Muñiz-Castillo Al, Rivera-Sosa A, Chollett I, Eakin CM, Andrade-Gómez L, McField M, Arias-González JE (2019) Three decades of heat stress exposure in Caribbean coral reefs: a new regional delineation to enhance conservation. Sci Rep 9:11013. doi:10.1038/s41598-019-47307-0

78. Nyström M, Folke C, Moberg F (2000) Coral reef disturbance and resilience in a human-dominated environment. Tree 15:1-5

79. Perry CT, Alvarez-Filip L (2018) Changing geo-ecological functions of coral reefs in the Anthropocene. Funct Ecol 33:1365-2435.13247. doi:10.1111/1365-2435.13247

80. Pinheiro HT, Bernardi G, Simon T, Joyeux JC, Macieira RM, Gasparini JL, Rocha C, Rocha LA (2017) Island biogeography of marine organisms. Nature 549:82-85. doi:10.1038/nature23680

81. Preskitt LB, Vroom PS, Smith CM (2004) A Rapid Ecological Assessment (REA) Quantitative Survey Method for Benthic Algae Using Photoquadrats with Scuba. Pacific Sci 58:201-209. doi:10.1353/psc.2004.0021

82. Putman RJ, Wratten SD (1984) Temporal Change in Community Structure and Function. In: Principles of Ecology. Springer Netherlands, Dordrecht, pp 86-104

83. Richardson LE, Graham NAJ, Pratchett MS, Hoey AS (2017) Structural complexity mediates functional structure of reef fish assemblages among coral habitats. Environ Biol Fishes 100:193207. doi:10.1007/s10641-016-0571-0

84. Richardson LE, Graham NAJ, Hoey AS (2020) Coral species composition drives key ecosystem function on coral reefs. Proc R Soc B Biol Sci doi. 10.1098/rspb.2019.2214 
85. Ricotta C, de Bello F, Moretti M, Caccianiga M, Cerabolini BEL, Pavoine S (2016) Measuring the functional redundancy of biological communities: a quantitative guide. Methods Ecol Evol 7:13861395. doi:10.1111/2041-210X.12604

86. Riul P, Targino CH, Farias JDN, Visscher PT, Horta PA (2008) Decrease in Lithothamnion sp. (Rhodophyta) primary production due to the deposition of a thin sediment layer. J Mar Biol Assoc United Kingdom 88:17-19. doi:10.1017/S0025315408000258

87. Sandin SA, Smith JE, DeMartini EE, Dinsdale EA, Donner SD, Friedlander AM, Konotchick T, Malay M, Maragos JE, Obura D, Pantos O, Paulay G, Richie M, Rohwer F, Schroeder RE, Walsh S, Jackson JBC, Knowlton N, Sala E (2008) Baselines and degradation of coral reefs in the Northern Line Islands. PLoS One. doi:10.1371/journal.pone.0001548

88. Schutte VGW, Selig ER, Bruno JF (2010) Regional spatio-temporal trends in Caribbean coral reef benthic communities. Mar Ecol Prog Ser 402:115-122. doi:10.3354/meps08438

89. Smith JE, Brainard R, Carter A, Dugas S, Edwards C, Harris J, Lewis L, Obura D, Rohwer F, Sala E, Vroom PS, Sandin S (2016) Re-evaluating the health of coral reef communities: baselines and evidence for human impacts across the central Pacific. Proc R Soc B Biol Sci 283:20151985. doi:10.1098/rspb.2015.1985

90. Soares MDO, Lemos VB, De Kikuchi RKP (2011) Aspectos biogeomorfológicos do Atol das Rocas, Atlântico Sul Equatorial. Rev Bras Geociencias 41:85-94

91. Solan M, Cardinale BJ, Downing AL, Engelhardt KAM, Ruesink JL, Srivastava DS (2004) Extinction and ecosystem function in the marine benthos. Science 306:1177-1180.

doi:10.1126/science. 1103960

92. Spalding MD, Grenfell AM (1997) New estimates of global and regional coral reef areas. Coral Reefs 16:225-230. doi:10.1007/s003380050078

93. Steneck RS, Dethier MN (1994) A Functional Group Approach to the Structure of Algal-Dominated Communities. Oikos 69:476. doi:10.2307/3545860

94. Villeger S, Miranda JR, Hernández DF, Mouillot D (2010) Contrasting changes in taxonomic vs. functional diversity of tropical fish communities after habitat degradation. Ecol Appl 20:1512-1522

95. Villéger S, Mason NWH, Mouillot D (2008) NEW MULTIDIMENSIONAL FUNCTIONAL DIVERSITY INDICES FOR A MULTIFACETED FRAMEWORK IN FUNCTIONAL ECOLOGY. Ecology 89:2290-2301. doi:10.1890/07-1206.1

96. Vroom P, Page K, Kenyon J, Brainard R (2006) Algae-Dominated Reefs. Am Sci 94:430. doi:10.1511/2006.61.430

97. Wahl M, Link H, Alexandridis N, Thomason JC, Cifuentes M, Costello MJ, da Gama BAP, Hillock K, Hobday AJ, Kaufmann MJ, Keller S, Kraufvelin P, Krüger I, Lauterbach L, Antunes BL, Molis M, Nakaoka M, Nyström J, bin Radzi Z, Stockhausen B, Thiel M, Vance T, Weseloh A, Whittle M, Wiesmann L, Wunderer L, Yamakita T, Lenz M (2011) Re-structuring of marine communities exposed to environmental change: A global study on the interactive effects of species and functional richness.

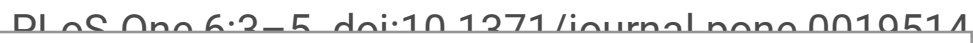


98. Ware C, Dijkstra JA, Mello K, Stevens A, O'Brien B, Ikedo W (2019) A novel three-dimensional analysis of functional architecture that describes the properties of macroalgae as a refuge. Mar Ecol Prog Ser 608:93-103. doi:10.3354/meps 12800

99. Whittaker RJ, Rigal F, Borges PAV, Cardoso P, Terzopoulou S, Casanoves F, Pla L, Guilhaumon F, Ladle RJ, Triantis KA (2014) Functional biogeography of oceanic islands and the scaling of functional diversity in the Azores. Proc Natl Acad Sci 111:13709-13714. doi:10.1073/pnas.1218036111

100. Wickham H, Winston C (2019) Create Elegant Data Visualisations Using the Grammar of Graphics. Packag "ggplot2." doi: 10.1093/bioinformatics/btr406

101. Williams GJ, Graham NAJ (2019) Rethinking coral reef functional futures. Funct Ecol 33:942-947. doi:10.1111/1365-2435.13374

102. Williams GJ, Graham NAJ, Jouffray J-B, Norström AV, Nyström M, Gove JM, Heenan A, Wedding LM (2019) Coral reef ecology in the Anthropocene. Funct Ecol 33:1014-1022. doi:10.1111/13652435.13290

103. Williams SE, Marsh H, Winter J (2002) Spatial Scale, Species Diversity, and Habitat Structure: Small Mammals in Australian Tropical Rain Forest. Ecology 83:1317. doi:10.2307/3071946

104. Wong JSY, Chan YKS, Ng CSL, Tun KPP, Darling ES, Huang D (2018) Comparing patterns of taxonomic, functional and phylogenetic diversity in reef coral communities. Coral Reefs 37:737-750. doi:10.1007/s00338-018-1698-6

105. Woodward G, Ebenman B, Emmerson M, Montoya JM, Olesen JM, Valido A, Warren PH (2005) Body size in ecological networks. Trends Ecol Evol 20:402-409. doi:10.1016/j.tree.2005.04.005

106. Zawada KJA, Madin JS, Baird AH, Bridge TCL, Dornelas M (2019a) Morphological traits can track coral reef responses to the Anthropocene. Funct Ecol 962-975. doi:10.1111/1365-2435.13358

107. Zawada KJA, Dornelas M, Madin JS (2019b) Quantifying coral morphology. Coral Reefs 38:12811292. doi:10.1007/s00338-019-01842-4

\section{Figures}




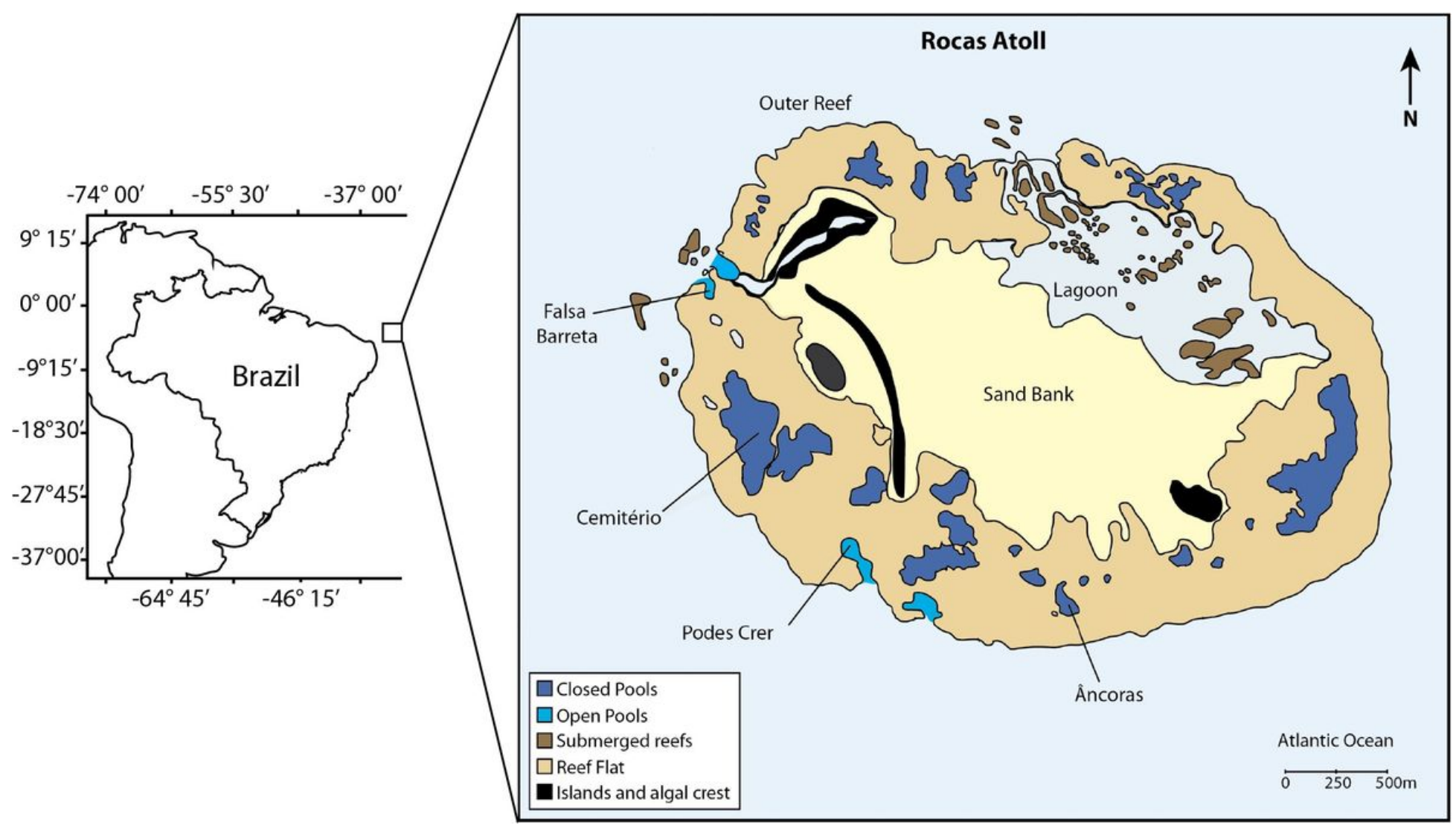

\section{Figure 1}

Location of Rocas Atoll and sampling sites during the seven years of monitoring indicated by arrows. Adapted from Longo et al. (2015). 


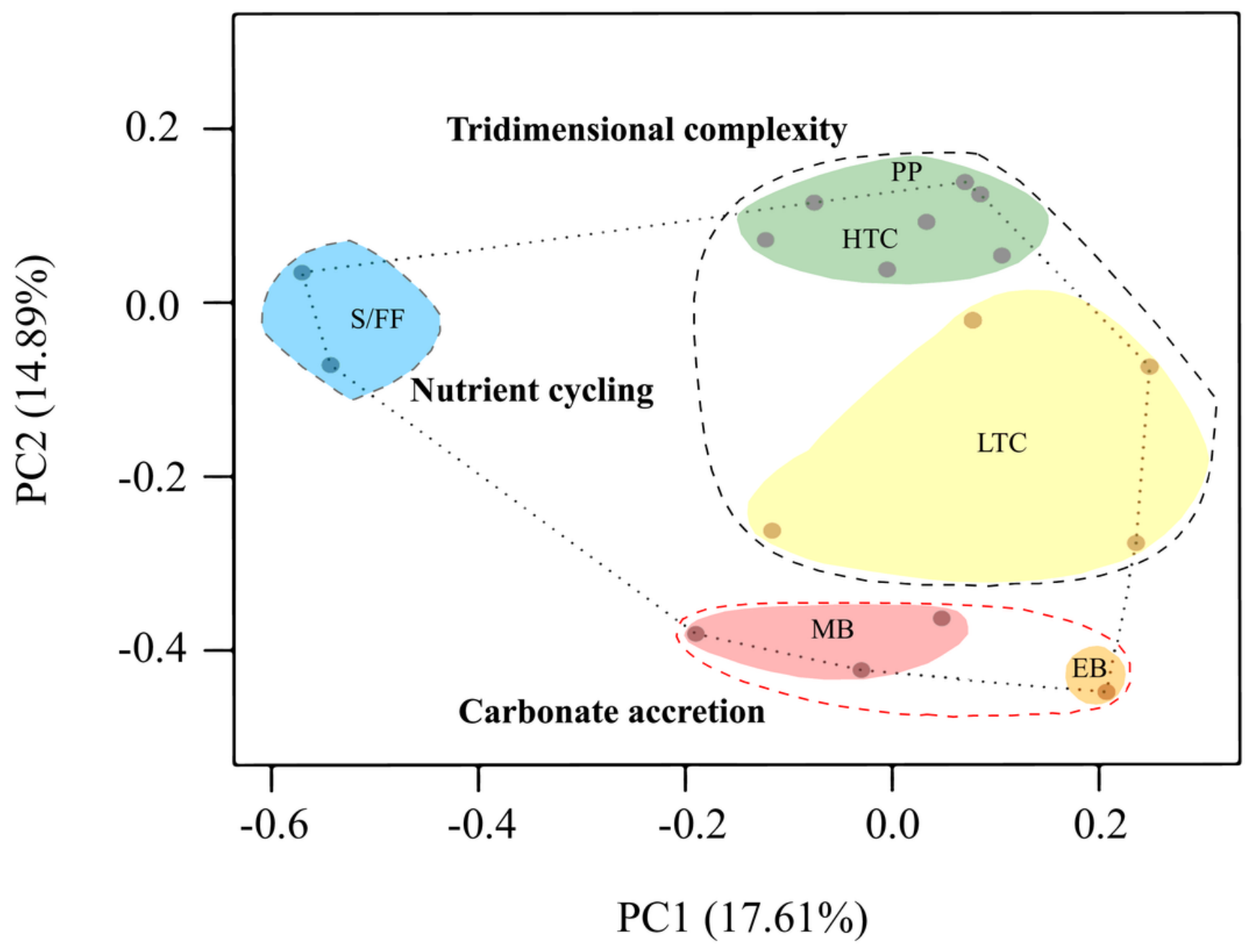

Figure 2

Position of functional entities (circles) in the multidimensional trait space considering all monitoring years. Dotted polygons represent the major ecosystem function performed by functional entities (tridimensional complexity, carbonate accretion and nutrient cycling). Filled polygons are groups of functional entities within specific ecosystem functions. PP: primary producers; HTC: high tridimensional complexity; LTC: low tridimensional complexity; EB: encrusting bioconstructors; MB: massive bioconstructors; S/FF: suspension/filter feeders. 

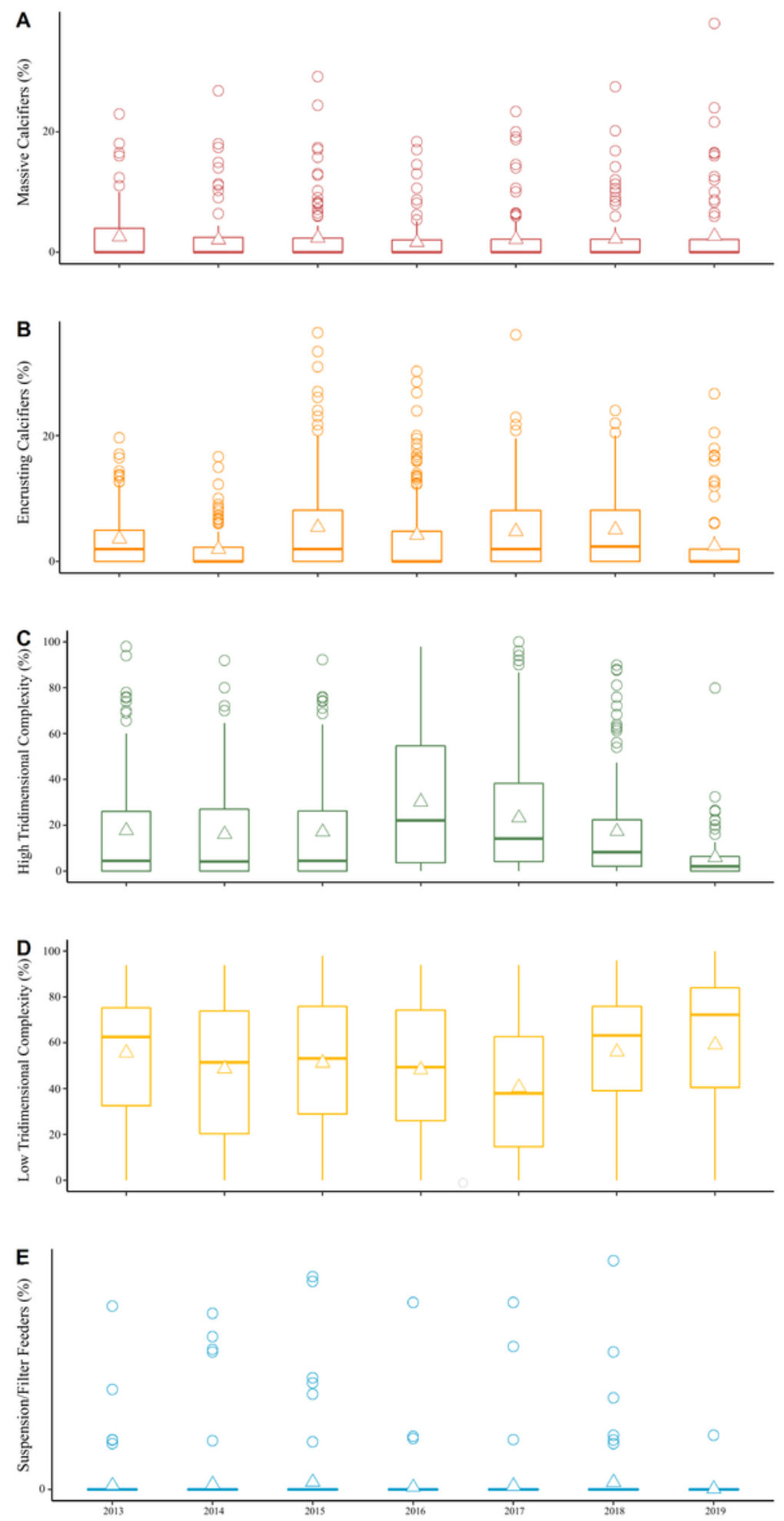

\section{Figure 3}

Percent cover dynamics from ecosystem functions (considering functional entities abundances), showing dominance of low tridimensional complexity function during our time series. Triangles represent mean percent cover and circles the outlier values. Mind the scale. (A) Massive calcifiers (e.g. corals as Siderastrea stellata) mean percent cover oscillated between 1.65-2.70\% (GLM p>0.05); (B) Encrusting Loading [MathJax]/jax/output/CommonHTML/fonts/TeX/fontdata.js 
tridimensional complexity (e.g. big macroalgae as Sargassum spp.) mean percent cover between 5.96$30.28 \%$ (GLM p <0.05); (D) Low tridimensional complexity (e.g. turf algae) mean percent cover between 40.56-59.18\% (GLM p<0.05); and (E) Suspension/Filter-feeders (e.g. sponges and/or ascidians) mean percent cover lower than $1 \%$ (GLM p>0.05).
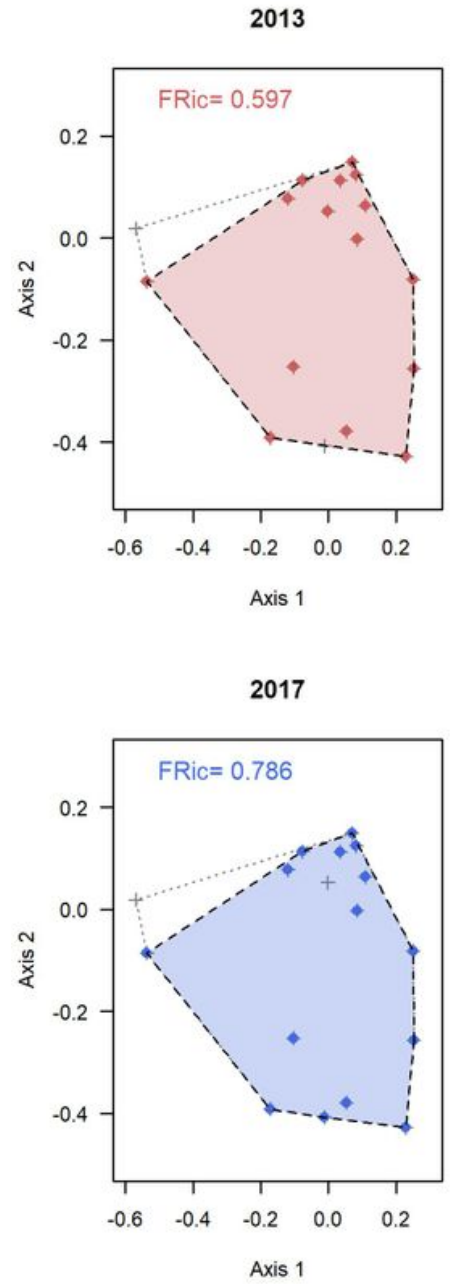

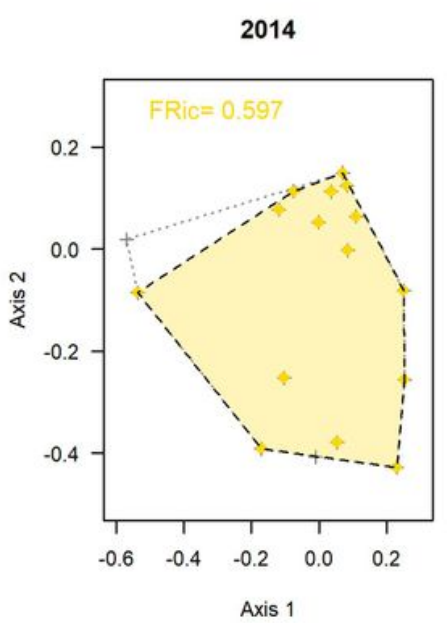

2018

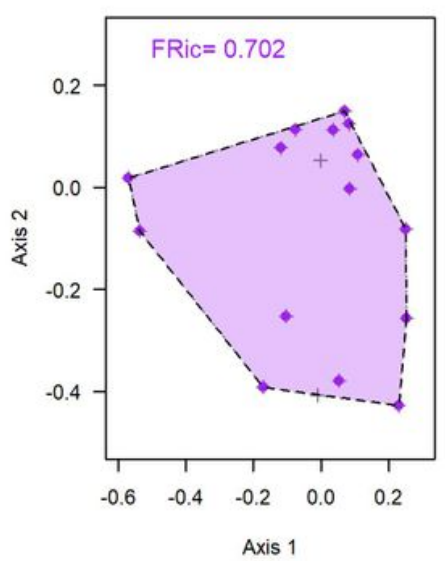

2015

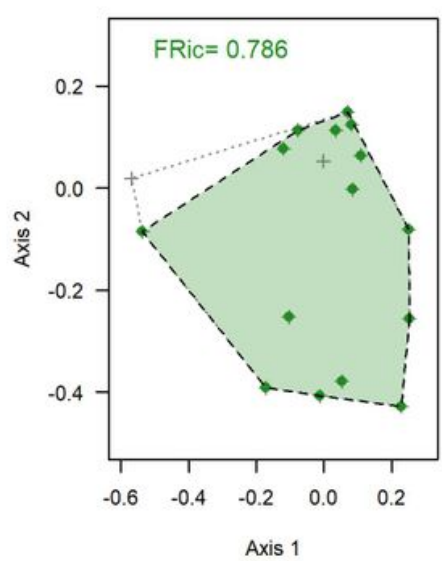

2019

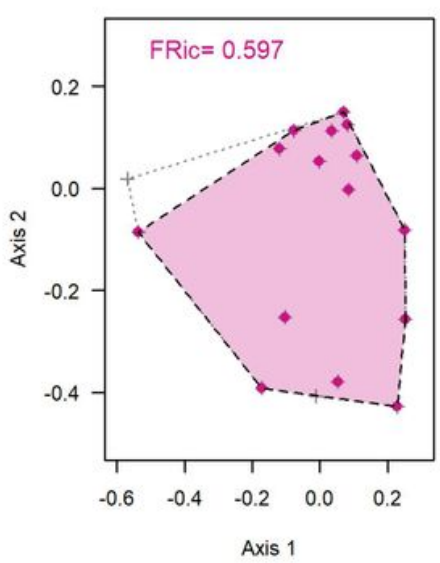

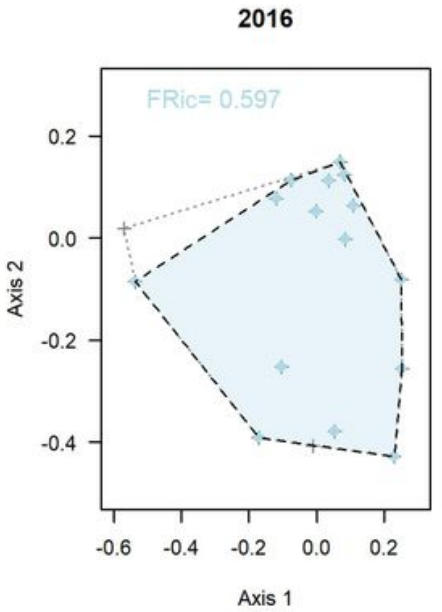

\section{Figure 4}

Volume occupied (Functional richness) in the functional space through years considering PCoA Axis 1 and 2. The total multidimensional trait space for all benthic morphospecies is presented in grey, with annual trait space overlaid in color. Dots denote the presence of functional entities, while crosses represent absent functional entities. 

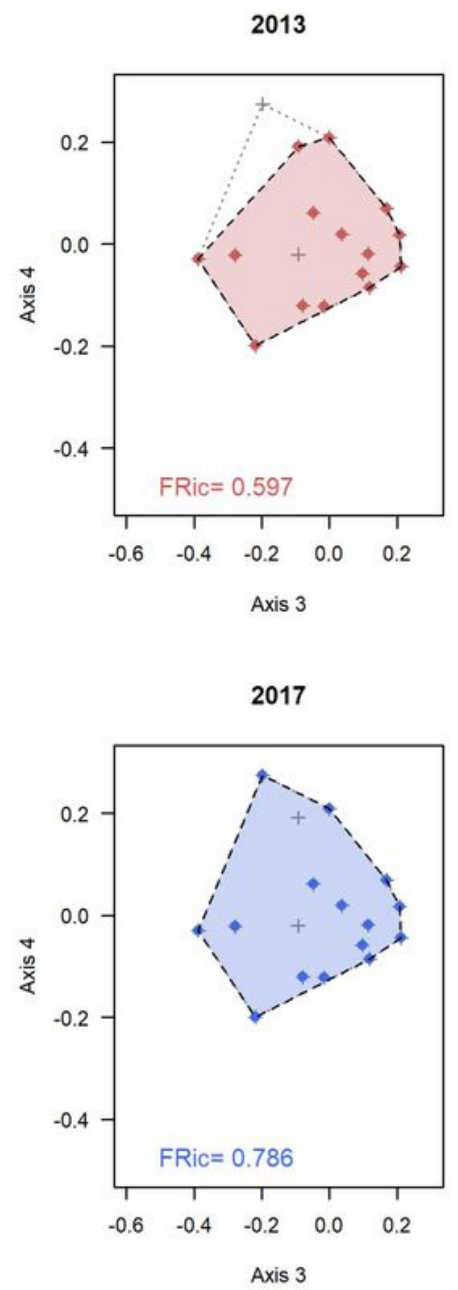

2014

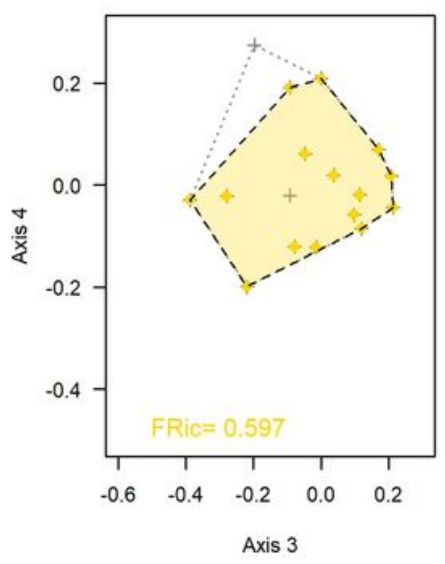

2018

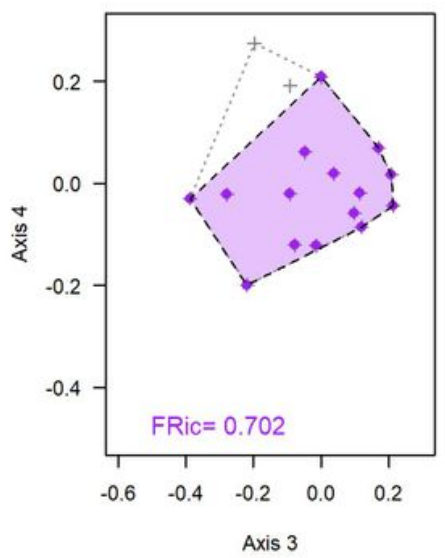

2015

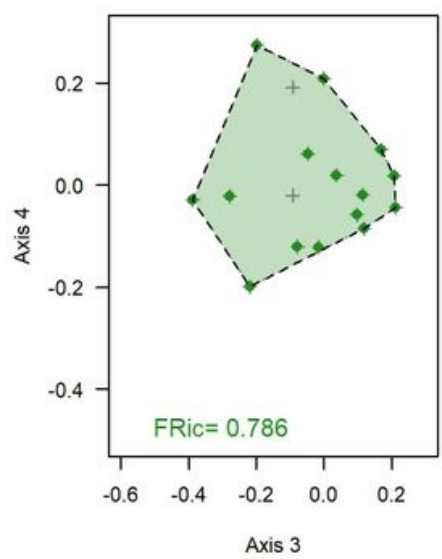

2019

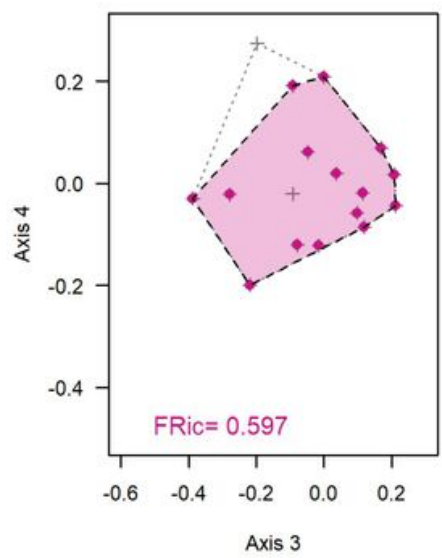

2016

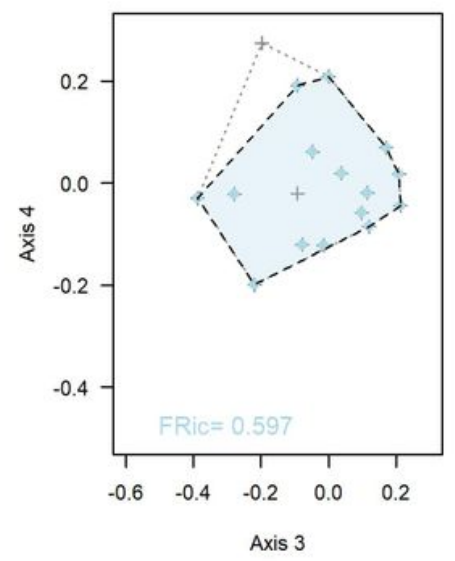

Axis 3

\section{Figure 5}

Volume occupied (Functional richness) in the functional space through years considering PCoA Axis 3 and 4. The total multidimensional trait space for all benthic morphospecies is presented in grey, with annual trait space overlaid in color. Dots denote the presence of functional entities, while crosses represent absent functional entities. 


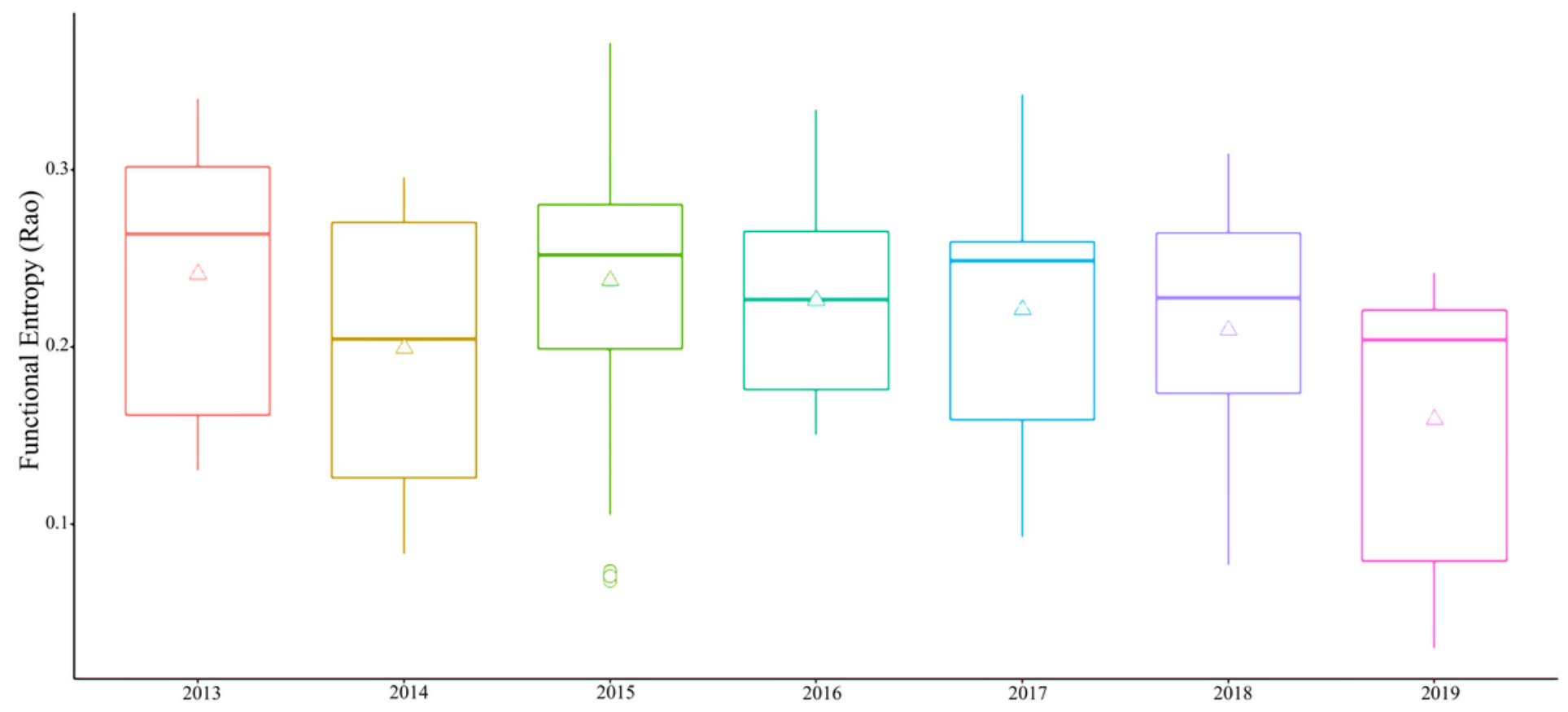

\section{Figure 6}

Functional entropy (FEnt) dynamics, indicating the evenness distribution of percent cover between functional entities with unique trait combination, that is, those located at functional space vertices. Higher FEnt values indicate a more even abundance distribution, while lower FEnt an uneven distribution. For Rocas Atoll, FEnt was generally low, showing dominance of some functional entities over others. Triangles represent mean FEnt values. Bars represent median values and circles the outliers. 